\title{
Erratum to: The effects of cyclooxygenase and nitric oxide synthase inhibition on oxidative stress in isolated rat heart
}

\author{
Nevena Barudzic $\cdot$ Drenka Turjacanin-Pantelic $\cdot$ Vladimir Zivkovic • \\ Dragica Selakovic • Ivan Srejovic • Jovana Joksimovic • \\ Dragan M. Djuric • Vladimir Lj. Jakovljevic
}

Published online: 28 June 2013

(C) Springer Science+Business Media New York 2013

Erratum to: Mol Cell Biochem

DOI 10.1007/s11010-013-1712-9

In the original article the name of one of the authors has erroneously been changed to Jovana Jakovljevic. The correct name of this author is: Jovana Joksimovic. Everything else in the paper remains correct.

The online version of the original article can be found under doi:10.1007/s11010-013-1712-9.

\footnotetext{
N. Barudzic · V. Zivkovic - D. Selakovic - I. Srejovic · J. Joksimovic · V. Lj. Jakovljevic ( $₫)$

Department of Physiology, Faculty of Medical Sciences, University of Kragujevac, Svetozara Markovica 69,

34000 Kragujevac, Serbia

e-mail: drvladakgbg@yahoo.com

D. Turjacanin-Pantelic · D. M. Djuric Institute of Medical Physiology "Richard Burian", School of Medicine, University of Belgrade, Belgrade, Serbia
} 